\title{
Clinical and prognostic factors in children with dilated cardiomyopathy
}

\author{
Dilate kardiyomyopatili çocuk hastalarda klinik ve prognostik faktörler
}

\author{
Ayça Koca Yozgat, Selmin Karademir
}

Gönderilme tarihi:19.12.2020

Kabul tarihi:30.04.2021

\begin{abstract}
Purpose: Dilated cardiomyopathy is characterized by impaired myocardial contractility and cardiac dilatation. Most cases in children are idiopathic despite diagnostic developments. In this study, we aimed to review children with dilated cardiomyopathy and attempt to determine the prognostic factors.

Materials and methods: A total of 59 children with a diagnosis of dilated cardiomyopathy were evaluated retrospectively between January 2005 to January 2013. The age of onset of symptoms, gender, parental consanguinity, electrocardiography findings, presence of cardiomegaly in the telecardiograpy, left ventricular ejection fraction and shortening fraction on prognosis were evaluated.

Results: The mean age of patients was $49.2 \pm 59.2$ months and the male/female ratio was $1.03 / 1$. Heart failure symptoms and signs were the most common cause of admission. The most common electrocardiographic finding was left ventricular hypertrophy in $32.2 \%$ and cardiomegaly was observed on telecardiography in $77.8 \%$. The left ventricular ejection and shortening fraction of patients' were $38.4 \pm 14.5 \%$ and $18.8 \pm 8.4 \%$ at the time of the diagnosis and $51 \pm 18.6 \%$ and $26.8 \pm 11.6 \%$ at the end of the follow-up, respectively. The mean follow-up period was $27.5 \pm 27.7$ months and the mortality rate was $42.4 \%$. The main factors affecting prognosis have been found as detection of electrocardiographic changes, cardiomegaly, and lower left ventricular ejection fraction at the time of the diagnosis.

Conclusion: Dilated cardiomyopathy remains a challenging disease and the prognosis is poor. In our study, the most important prognostic markers affecting survival were determined by the presence of electrocardiographic changes, cardiomegaly, and a reduced ejection fraction.
\end{abstract}

Key words: Children, dilated cardiomyopathy, prognostic factors.

Koca Yozgat A, Karademir S. Clinical and prognostic factors in children with dilated cardiomyopathy. Pam Med J 2021;14:828-834.

Öz

Amaç: Dilate kardiyomiyopati, sol ventrikül kontraktilitesinde bozulma ve kardiyak dilatasyon ile seyreden bir hastalıktır. Tanısal ilerlemelere rağmen çocuklardaki çoğu vaka idiyopatiktir. Çalışmamızda dilate kardiyomiyopatili çocuk hastalarda prognozu etkileyen faktörleri değerlendirmeyi amaçladık.

Gereç ve yöntem: Dilate kardiyomiyopati tanısı konulan 59 hasta, Ocak 2005-Ocak 2013 tarihleri arasında retrospektif olarak incelendi. Prognoz açısından; hastalarda semptomların başlama yaşı, hastaların cinsiyeti, anne-baba akrabalığı, elektrokardiyografik bulgu ve telekardiyogramda kardiyomegali varlığı, ekokardiyografide ejeksiyon fraksiyonu ve kısalma fraksiyonu değerlendirildi.

Bulgular: Hastalarımızın ortalama yaşları 49,2 $\pm 59,2$ ay olup, erkek/kız oranı 1,03/1 idi. Hastalar en sık kalp yetersizliği semptom ve klinik bulguları ile başvurmuştu. En sık elektrokardiyografi bulgusu sol ventrikül hipertrofisi $(\% 32,2)$ idi ve telekardiyografide hastaların \% 77,8 'inde kardiyomegali saptandı. Ekokardiyografik incelemede; hastaların sol ventrikül ejeksiyon ve kısalma fraksiyonları tanı anında $\% 38,4 \pm 14,5$ ve $\% 18,8 \pm 8,4$ olup, takip süresi sonunda ise $\% 51 \pm 18,6$ ve $\% 26,8 \pm 11,6$ idi. Ortalama takip süresi $27,5 \pm 27,7$ ay ve mortalite oranı $\% 42,4$ olarak bulundu. Prognozu etkileyen ana faktörler incelendiğinde; tanıda hastalarda elektrokardiyografik değişiklik, kardiyomegali olması ve ejeksiyon fraksiyonlarının düşük olmasının sağkalımı etkilediği görüldü.

Sonuç: Dilate kardiyomiyopati tedavisi zor bir hastalıkdır ve prognozu kötüdür. Tanı anında elektrokardiyografik bulgu ve telekardiyografide kardiyomegali olması ve EF değerlerinin düşük olması hastaların sağkalımını etkileyen en önemli belirteçlerdir.

Anahtar kelimeler: Çocuk, dilate kardiyomiyopati, prognostik faktörler.

Koca Yozgat A, Karademir S. Dilate kardiyomyopatili çocuk hastalarda klinik ve prognostik faktörler. Pam Tıp Derg 2021;14:828-834.

Ayça Koca Yozgat, MD, Department of Pediatric Hematology and Oncology, Ankara City Hospital of Ankara Health Sciences University, Ankara, Turkey, e-mail: draycayozgat@yahoo.com (https://orcid.org/0000-0001-6690-721X) (Corresponding Author)

Selmin Karademir, Department of Pediatric Cardiology, Düzce University School of Medicine, Düzce, Turkey, e-mail: selminkarademir@yahoo. com (https://orcid.org/0000-0002-9084-0083) 


\section{Introduction}

Dilated cardiomyopathy (DCM) is the most common cardiyomyopathy and a considerable cause of mortality in children [1]. Dilated cardiomyopathy is a myocardial disorder characterized by impaired myocardial contractility and cardiac dilatation that causes congestive failure of the heart. The annual incidence of DCM is 0.34 to 1.13 per 1 million children [2]. The etiology is varied but most of the cases in children are idiopathic; the remainder are secondary to various factors, such as familial, infectious myocarditis, mitochondrial, metabolic or malformation syndromes and neuromuscular disease [3]. Descripiton of familial cardiomyopathy with or without a specific genetic mutation may be important for the treatment of family members [4].

The prognosis of patients with DCM is in a wide spectrum between sudden recovery and severe heart failure. In prior studies from the Pediatric Cardiomyopathy Registry, the survival rates of patients range from 75 to $80 \%$ and from 60 to $75 \%$, at one to five years, respectively [4, 5].

Despite advances in treatment, such as $\beta$-blockers, diuretics and angiotensin converting enzyme inhibitors, the prognosis of DCM in children remains poor, and organ survival has changed little over the past 20 years. Currently the only effective treatment in patients who unresponsive to medical treatment is cardiac transplantation [6].

In pediatric patients, prognostic factors of DCM are not well identified until now because of the diseases heterogeneity. In children the published data are rare and little is known about long-term clinical course and factors that may influenced prognosis, better or worse. Identifying the prognostic factors for patients who have a poor outcome is necessary and thus, cardiac transplantation could be offered to those patients as a therapeutic option.

In this study we aimed to review the children with dilated cardiomyopathy and attempt to determine prognostic factors.

\section{Material and methods}

This retrospective study comprised of 59 children with dilated cardiomyopathy at Dr.
Sami Ulus Maternity, Child Health and Diseases Training and Research Hospital between January 2005 to January 2013 and this is the first authors' pediatric thesis because of a retrospective study, there is no ethics committee approval. The diagnosis of DCM was based on the presence of ventricular enlargement and systolic dysfunction with normal left ventricles wall thickness in echocardiography determined by the American Heart Association in 2006 [7].

Patients with congenital cardiac disease, arrhythmogenic and other cardiomyopathies, Kawasaki's disease, ischaemic cardiac diseases, systemic arterial hypertension, cardiomyopaties due to cardiotoxic agents and inborn errors of metabolism, neuromuscular disease, rheumatic heart disease, septicaemia, Chagas' disease were all excluded.

Clinical records of 59 patients were analyzed for data on age, gender, consanguinity between parents, familial history, complaints on presentation, physical examination findings, electrocardiography (ECG) and echocardiography findings at the time of diagnosis and prognosis.

The age of onset of symptoms, gender, consanguinity between parents, ECG findings, presence of cardiomegaly in the telecardiography, left ventricular ejection fraction (LVEF) and shortening fraction (LVFS) measurements on prognosis were evaluated. The survival of the patients was evaluated from the time of diagnosis.

\section{Statistical analysis}

Statistical analyses were performed using the SPSS 15.0 programme (Statistical package for the social sciences IBM Corp., Armonk, NY, USA). Comparative variables were reported as mean and range. Whether continuous variables fit the normal distribution was evaluated using visual (histogram and probability plots) and analytical tests (Kolmogorov-Smirnov/ShapiroWilk tests). Independent sample t-test was used for comparative analysis between the two groups, and the Mann-Whitney $U$ test was used for data that did not conform to the normal distribution. Pearson chi-square test was used in comparison analysis for categorical variables between independent groups. The differences with a $p$-value of less than 0.05 were considered as statistically significant and the confidence 
interval was $95 \%$. The survival times of the patients were evaluated using Kaplan-Meier method and Cox regression analysis.

\section{Results}

The mean age of patients was $49.2 \pm 59.2$ months (10 days-183 months) and 32 patients $(54.2 \%)$ were under, and 27 patients $(45.8 \%)$ above two years of age. Thirty $(50.8 \%)$ of the patients were female and $29(49.2 \%)$ were male. Parental consanguinity and familial history of DCM were determined in 24 (40.7\%) and in $1(1.6 \%)$ patients, respectively. A history of pneumonia or upper respiratory tract infection was defined in $41(69.4 \%)$ patients within a month before diagnosis.

Heart failure symptoms and signs were the most common cause of admission in both age groups $(n=40,67.7 \%)$. The most common physical examination findings were $2-3 / 6$ degree systolic murmur heard at apical localization $(n=43,72.8 \%)$ and tachycardia $(n=38,64.3 \%)$. Table 1 shows the complaints and physical examination findings on the presentation of the 59 patients.
On electrocardiography, the most common findings were left ventricular hypertrophy in 19 patients $(32.2 \%)$, right ventricular hypertrophy in $6(10.1 \%)$, ST-T changes in $5(10.1 \%)$, voltage suppression in $4(8.4 \%)$, arrhytmia in $3(6.7 \%)$, and biventricular hypertrophy in 1 $(1.6 \%)$ patients. Of 4 patients with arrhythmia, 1 had supraventricular tachycardia and 3 had ventricular extrasystoles. Cardiomegaly was present in $46(77.8 \%)$ of the patients in the telecardiography.

At the time of the diagnosis, in the transthoracic echocardiographic examinations, mean left ventricle end-diastole diameter (LVEDd) was determined as $41.57 \pm 2.5 \mathrm{~mm}$, mean LVEF as $38.4 \pm 14.5 \%$, mean LVFS as $18.8 \pm 8.4 \%$. At the end of the follow-up period, the mean LVEF was $51 \pm 18.6 \%$ and mean LVFS was $26.8 \pm 11.6 \%$. According to age groups of 2 years LVEF and LVFS values are shown in Table 2.

The median follow-up period of our patients was 21.2 months, ranged from 1 day to 86 months. Two (3.3\%) patients underwent cardiac

Table 1. Complaints and physical examination findings at the time of diagnosis

\begin{tabular}{lll}
\hline & Number & $\%$ \\
\hline Complaints $^{*}$ & 38 & \\
Cough & 32 & 54.3 \\
Shortness of breath & 29 & 49.1 \\
Anorexia & 27 & 45.6 \\
Weakness & 22 & 36 \\
Fever & 17 & 28.7 \\
Nausea-vomiting & 14 & 23.6 \\
Palpitations & 12 & 20.2 \\
Sweating & 10 & 16.8 \\
Bruising & 19 & 32 \\
Other complaints** & & \\
Physical examination findings & & \\
Cardiac murmur & 43 & 72.8 \\
Tachycardia & 38 & 64.3 \\
Tachypnea & 27 & 45.7 \\
Hepatomegaly & 24 & 40.6 \\
Galo rhythm & 10 & 16.8 \\
Edema & 7 & 11.8 \\
Other physical examination findings ${ }^{* * *}$ & 13 & 22 \\
\hline Somien & & \\
\hline
\end{tabular}

*Some patients have more than one complaint and physical examination finding

** Chest pain, growth failure, abdominal pain, headache

*** Splenomegaly, retarded neuromotor development, venous distension, clubbing 
transplantation. Mortality was seen in 25 (42.4\%) patients at median 7.5 months (1-26 months) after diagnosis, and 34 (57.6\%) survived. One of our patients who underwent transplantation died.

The patients included in the study were divided into two groups, Group I as survivors and Group II as non-survivors. Age, gender, parental consanguinity, presence of ECG changes, presence of cardiomegaly on telecardiography, LVEF, LVFS measurement were compared in terms of patients' prognosis.

Mortality was seen in 11 patients aged <2 years and in 14 patients aged 2 years or older. The mortality rate was found to be higher in female patients $(n=14,46.7 \%)$ than in male patients $(n=11,38 \%)$ and mortality was seen in $14(58.4 \%)$ patients with and eleven patients $(31.5 \%)$ without parental consanguinity. In the present study, no statistically significant difference was found between the groups in age, gender and parental consanguinity $(p>0,05)$.

While the mortality rate was $50 \%$ in patients with ECG changes at the time of the diagnosis and twenty-two patients (47.8\%) with cardiomegaly as determined on telecardiography were died. Electrocardiographic changes and rate of cardiomegaly was defined at a higher rate in group II $(p<0.05)$.

In the evaluation of the echocardiography findings at diagnosis, the mean LVEF values were lower in Group II than in Group I and the difference between survivors and nonsurvivors was statistically significant $(p=0.04)$. The characteristics of Group I and Group II are shown in Table 3.

\section{Discussion}

Dilated cardiomyopathy is a myocardial disease which produces a dilated left ventricle with systolic dysfunction and it is the main indication for a heart transplant in children and adults [8]. A significant proportion of pediatric patients with DCM remain classified as idiopathic, despite advances in diagnosis [9]. Jr Dec et al. [10] showed that, when myocardial biopsy is performed in patients with DCM, the disease is secondary to myocarditis in most patients who are thought to be idiopathic. Although there are many reasons other than idiopathic, post-myocarditis dilated cardiomyopathy being the most prevalent form [11]. In our study, 41 patients $(69.4 \%)$ had a history of pneumonia or upper respiratory tract infection within the previous month and this suggests myocarditis secondary to infection is important in etiology.

In our study, the parental consanguinity rate was $40.7 \%$ and one of our patients had a family history of DCM. Cardiological evaluations of the family members of this patient were found to be normal. In patients with dilated cardiomyopathy, screening cases among family members is substantial in terms of reducing the mortality of the disease and early diagnosis. As in our study, because of the high rate of consanguineous marriage in our country, we think that a detailed cardiological examination should be done on family members.

The clinical presentation may vary from asymptomatic to acute congestive heart failure and tachypnea, tachycardia, hepatomegaly in children with DCM and a systolic murmur of mitral regurgitation are the most frequent symptoms and signs. In our study we also found that the most common physical examination findings were 2-3/6 degree systolic murmur and tachycardia.

The 5-year transplant free survival rate in pediatric patients with DCM ranges from 50$60 \%$ [12]. In our study group, the mortality rate was determined as $42.4 \%$ at a median of 7.5 months after diagnosis, similar to the rates in the literature.

The relationship between age, gender and parental consanguinity and prognosis has been evaluated. But we found that age, gender and parental consanguinity did not have any effect on mortality in patients with DCM. Burch et al. [13] stated that mortality was higher in those over 2 years of age. Similarly, Daubenay et al. [6] reported that the prognosis was poor in patients over 5 years of age at the time of diagnosis. Although in our study, we found high mortality rate in patients over 2 years of age but we think about that we could not find a significant difference due to the limited number of patients.

Arrhythmia and left ventricular hypertrophy cause a major risk in children with DCM and ST and $T$ wave changes, pathologic $Q$ wave which are ischemia findings of electrocardiography were also seen [14]. In our study, the most 
Table 2. Echocardiographic findings of the patients at the time of the diagnosis, and at the end of the follow-up period

\begin{tabular}{|c|c|c|c|c|c|c|}
\hline & \multicolumn{2}{|c|}{$<2$ years $(\mathrm{n}: 32)$} & \multicolumn{2}{|c|}{$\geq 2$ years $(\mathrm{n}: 27)$} & \multirow[b]{2}{*}{$p^{1 \ddagger}$} & \multirow[b]{2}{*}{$p^{2 \ddagger}$} \\
\hline & LVEF & LVFS & LVEF & LVFS & & \\
\hline At diagnosis & $38.2 \pm 11.2$ & $18.2 \pm 5.7$ & $38.6 \pm 17.9$ & $19.5 \pm 10.9$ & 0.92 & 0.56 \\
\hline $\begin{array}{l}\text { At the end of the } \\
\text { follow-up }\end{array}$ & $52.2 \pm 19.8$ & $27.3 \pm 12.5$ & $49.5 \pm 17.3$ & $26.2 \pm 10.7$ & 0.58 & 0.71 \\
\hline
\end{tabular}

LVEF, left ventricular ejection fraction; LVFS, left ventricular shortening fraction;

$\ddagger$ : Independent T test; $p^{1}, p$ value between LVEF, $p^{2}, p$ value between LVFS

Table 3. Characteristics of Group I and Group II

\begin{tabular}{|c|c|c|c|c|c|c|}
\hline & \multicolumn{2}{|c|}{$\begin{array}{l}\text { Group I } \\
\text { (Survivors) (n:34) }\end{array}$} & \multicolumn{2}{|c|}{$\begin{array}{l}\text { Group II } \\
\text { (Non-survivors) (n:25) }\end{array}$} & \multirow[t]{2}{*}{ Total } & \multirow[b]{2}{*}{$p$ value } \\
\hline & $\mathrm{n}$ & $\%$ & $\mathrm{n}$ & $\%$ & & \\
\hline \multicolumn{7}{|l|}{ Age } \\
\hline$<2$ years & 21 & 65.6 & 11 & 34.4 & 32 & $>0.05^{*}$ \\
\hline$\geq 2$ years & 13 & 48.1 & 14 & 51.9 & 27 & \\
\hline Gender & & & & & & $>0.05^{*}$ \\
\hline Male & 18 & 62 & 11 & 38 & 29 & \\
\hline Female & 16 & 53.3 & 14 & 46.7 & 30 & \\
\hline Consanguinity & & & & & & $>0.05^{*}$ \\
\hline Yes & 10 & 41.6 & 14 & 58.4 & 24 & \\
\hline No & 24 & 68.5 & 11 & 31.5 & 35 & \\
\hline $\begin{array}{l}\text { Electrographic } \\
\text { changes }\end{array}$ & & & & & & $0.04^{*}$ \\
\hline Yes & 19 & 50 & 19 & 50 & 38 & \\
\hline No & 15 & 71.5 & 6 & 28.5 & 21 & \\
\hline $\begin{array}{l}\text { Presence of } \\
\text { cardiomegaly }\end{array}$ & & & & & & $0.03^{*}$ \\
\hline Yes & 24 & 52.2 & 22 & 47.8 & 46 & \\
\hline No & 10 & 77 & 3 & 23 & 13 & \\
\hline \multicolumn{7}{|c|}{$\begin{array}{l}\text { Echocardiography } \\
\text { findings }\end{array}$} \\
\hline LVEF & \multicolumn{2}{|c|}{$41.7 \pm 13.8 \%$} & \multicolumn{2}{|c|}{$34 \pm 14.5 \%$} & & $0.04^{\ddagger}$ \\
\hline LVFS & \multicolumn{2}{|c|}{$20.3 \pm 8.2 \%$} & \multicolumn{2}{|c|}{$16.8 \pm 8.4 \%$} & & $>0.05 \ddagger$ \\
\hline
\end{tabular}

LVEF, left ventricular ejection fraction; LVFS, left ventricular shortening fraction;

*: Pearson chi-square test; ${ }^{\ddagger}$ :Independent T-Test 
common electrocardiography finding was left ventricular hypertrophy and we observed that the mortality rate was statistically higher in patients with ECG findings. Türe et al. [15] reported that, the significant difference was seen between the electrocardiographic findings of deceased and surviving patients with DCM and they suggest that detailed ECG wave measurements should be evaluated in children to define the risk of mortality.

In our study, $77.8 \%$ of our patients had cardiomegaly as detected in telecardiography and the mortality of patients with cardiomegaly was higher than those without. Similarly, in the literature, cardiomegaly has been shown to be a predictor of prognosis in patients with DCM [16].

Many studies in the literature have investigated the relationship between left ventricular function and prognosis in patients with DCM. Zecchin et al. [17] reported that patients whose LVEF lower than $30 \%$ and a longer left ventricular end-diastolic diameter had a poor prognosis. Daubeney et al. [6] stated that risk factors for a poorer outcome included a lower LVFS at presentation. In our study group, the mean LVEF at presentation was statistically significantly lower in non-survivors. Also, the mean LVFS at the time of diagnosis was lower in non-survivors, but no statistical difference was found.

Our study has some limitations due to the fact that the study was retrospective and study sample size was small. Consequently, statistical significance could not be reached in some data and larger prospective studies should be required to support the results of our study.

Despite medical treatment and efforts to advance patient care, pediatric DCM remains a challenging disease and the prognosis is poor. Cardiac transplantation should be considered in patients with intractable advanced symptomatic heart failure and require multiple inotropes and mechanical ventilation [18]. Adwani et al. [19] reported that the survival rate of pediatric patients who underwent cardiac transplantation for DCM was $95 \%$ at one year and $87 \%$ at three years. In our study, cardiac transplantation was performed in two $(3.3 \%)$ patients and one died after transplantation.
In conclusion, there were no significant difference between survivors and nonsurvivors in respect of age, gender and parental consanguinity. Whereas, in our study the main factors affecting prognosis have been found as detection of ECG changes on electrocardiography, cardiomegaly on telecardiography and lower LVEF at the time of the diagnosis in patients with DCM. Further studies are needed to determine the factors predicting mortality in patients with dilated cardiomyopathy.

Conflict of interest: No conflict of interest was declared by the authors.

\section{References}

1. Nugent AW, Daubeney PEF, Chondros $P$, et al. National Australian Childhood Cardiomyopathy Study. The epidemiology of childhood cardiomyopathy in Australia. N Engl J Med 2003;348:1639-1646. https:// doi.org/10.1056/NEJMoa021737

2. Richardson P, McKenna W, Bristow M, et al. Report of the 1995 World Health Organization/International Society and Federation of Cardiology task force on the definition and classification of cardiomyopathies. Circulation 1996;93:841-842. https://doi. org/10.1161/01.cir.93.5.841

3. Lipshultz SE, Sleeper LA, Towbin JA, et al. The incidence of pediatric cardiomyopathy in two regions of the United States. N Engl J Med 2003;348:1647-1655. https://doi.org/10.1056/NEJMoa021715

4. Cox GF. Diagnostic approaches to pediatric cardiomyopathy of metabolic genetic etiologies and their relation to therapy. Prog Pediatr Cardiol 2007;24:1525. https://doi.org/10.1016/j.ppedcard.2007.08.013

5. Towbin JA, Lowe AM, Colan SD, et al. Incidence, causes, and outcomes of dilated cardiomyopathy in children. JAMA 2006;296:1867-1876. https://doi. org/10.1001/jama.296.15.1867

6. Daubeney PE, Nugent AW, Chondros $\mathrm{P}$, et al. National Australian Childhood Cardiomyopathy Study. Clinical features and outcomes of childhood dilated cardiomyopathy: results from a national populationbased study. Circulation 2006;114:2671-2678. https:// doi.org/10.1161/CIRCULATIONAHA.106.635128

7. Maron BJ, Towbin CJA, Thiene FG, et al. Contemporary definitions and classification of the cardiomyopathies: an American Heart Association scientific statement from the Council on Clinical Cardiology, Heart Failure and Transplantation Committee; quality of care and outcomes research and functional genomics and translational biology interdisciplinary working groups; and council on epidemiology and prevention. Circulation 2006;113:1807-1816. https://doi. org/10.1161/CIRCULATIONAHA.106.174287 
8. Naudi D, Rossano JW. Epidemiology and Cost of heart failure in children. Cardiol Young 2015;25:1460-1468. https://doi.org/10.1017/S1047951115002280

9. Puggia I, Merlo M, Barbati G, et al. Natural history of dilated cardiomyopathy in children. J Am Heart Assoc 2016;5:e003450. https://doi.org/10.1161/ JAHA. 116.003450

10. DecGW Jr, Palacios IF, Fallon JT, etal.Active myocarditis in the spectrum of acute dilated cardiomyopathies. Clinical features, histologic correlates, and clinical outcome. N Engl J Med 1985;312:885-890. https://doi. org/10.1056/NEJM198504043121404

11. Lipshultz SE, Law YM, Asante Korang A, et al. Cardiomyopathy in children: classification and diagnosis: a scientific statement from the American Heart Association. Circulation 2019;140:9-68. https:// doi.org/10.1161/CIR.0000000000000682

12. Alvarez JA, Orav EJ, Wilkinson JD, et al. Competing risks for death and cardiac transplantation in children with dilated cardiomyopathy: results from the pediatric cardiomyopathy registry. Circulation 2011;124:814-823. https://doi.org/10.1161/ CIRCULATIONAHA. 110.973826

13. Burch M, Siddiqi SA, Celermajer DS, Scott C, Bull C, Deanfield JE. Dilated cardiomyopathy in children: determinants of outcome. Br Heart J 1994;72:246-250. https://doi.org/10.1136/hrt.72.3.246

14. Muller G, Ulmer HE, Hagel KJ, Wolf D. Cardiac dysrhythmias in children with idiopathic dilated or hypertrophic cardiomyopathy. Pediatr Cardiol 1995;16:56-60. https://doi.org/10.1007/BF00796818

15. Türe $M$, Balık $H$, Akın A, Bilici $M$, Nergiz A. The relationship between electrocardiographic data and mortality in children diagnosed with dilated cardiomyopathy. Eur J Pediatr 2020;179:813-819. https://doi.org/10.1007/s00431-020-03569-9

16. Manolio TA, Baughman KL, Rodeheffer $\mathrm{R}$, et al. Prevalence and etiology of idiopathic dilated cardiomyopathy (summary of a National Heart, Lung, and Blood Institute workshop. Am J Cardiol 1992;69:1458-1466. https://doi.org/10.1016/00029149(92)90901-a

17. Zecchin M, Lenarda AD, Bonin M, et al. Incidence and predictors of sudden cardiac death during long-term follow-up in patients with dilated cardiomyopathy on optimal medical therapy. Ital Heart J 2001;2:213-221.

18. Jefferies JL, Towbin JA. Dilated cardiomyopathy. Lancet 2010;375:752-762. https://doi.org/10.1016/ S0140-6736(09)62023-7

19. Adwani SS, Whitehead BF, Rees PG, et al. Heart transplantation for dilated cardiomyopathy. Arch Dis Child 1995;73:447-452. https://doi.org/10.1136/ adc.73.5.447
Acknowledgement: This manuscript is the thesis of the first author and it was produces under the supervision of the second author.

Ethics committee approval: This article is the first authors' pediatric thesis, which was made in 2013. Since it is a retrospective study, there is no ethics committee approval.

\section{Contributions of the authors to the article}

A.K.Y. conceptualized and designed the study, drafted the initial manuscript, collected data, carried out the initial analyses, and reviewed and revised the manuscript. S.K. conceptualized and designed the study, coordinated and supervised data collection. All authors approved the final manuscript as submitted and agree to be accountable for all aspects of the work. 